\title{
Outside the Whale Scholarship and Commitment
}

\author{
Jeremy Caple \\ Edward W. Said, Culture and Imperialism (New York: Alfred A Knopf 1993). \\ E.P. Thompson, Customs in Common (London: Merlin Press 1991).
}

Edward Said and Edward Thompson share common ground in several respects but for our purposes it is the commonality of the outsider experience that is most apposite and one which informs their analyses of the role of culture; literary culture in the case of Said and "plebeian" culture in the case of Thompson. Thompson was long the outsider in British history and spent only a few years with a permanent university position, choosing instead to teach as an itinerant, travelling mostly in the United States, and to spend as much time as possible at home writing. He spent the 1980s as leader of the peace movement in Europe, becoming a celebrity in the process, and demonstrating that indeed a historian could make a difference in politics through direct involvement and through the pen. His influence in the historical profession is profound; even those with whom he disagreed, and there were many, felt the need to address historical problems raised by Thompson. Said holds a professorship at Columbia University but he too is an outsider; a Palestinian who grew up learning more about England and its language than his own culture and language - and who now teaches in the United States - he represents all the tensions inherent in the role of an accepted immigrant who also acts as a spokesman for a cause unpopular in his new country. As an academic Said is accorded the respect he deserves; as a political activist he finds it difficult to get anyone to listen. ${ }^{l}$

At first glance there appears little to tie Edward Said's Culture and Imperialism to E.P. Thompson's Customs in Common. Said's work deals with the relationship between the literary culture of imperialist countries and the process of imperialism, whilst Thompson deals with various aspects of plebeian culture and custom of eighteenth-century English society. There are however some obvious connections which become apparent upon first reading; Said deals with the culture of dominance and Thompson offers a description of a culture of resistance. For Said culture, especially literary culture, provides a series of insights into the relationship between imperialism and the casual habit of rule which pervaded British and French societies; he uses the work of Jane Austen, Charles Dickens, Joseph Conrad and Albert Camus

1 On the experience of the writer as outsider and the problems of unpopular political views, see Salman Rushdie, Imaginary Homelands (London 1991). 
to make a series of important points about the assumptions which inform the role of the metropolitan centre and the colonies in these writers. Thompson's work deals with the other side of the coin; in a series of essays Thompson advances our understanding of the material force of custom and plebeian culture in eighteenth-century England. It was a robust culture of resistance to the advance of agrarian capitalism and a world governed by political economy.

\section{One}

Imperialism has been a contentious topic for almost the past one hundred years but the past four decades have witnessed a profound and significant transformation in the level of the debate. Decolonization during the postwar years has meant that the debate has become less academic and increasingly rooted in the dialogue between the decaying imperial centre and the former colonies. It is a dialogue of blame and one of confrontation and occasionally an attempt to come to grips with the heretical notion that imperialism cannot be held responsible for every ill that the contemporary Third World experiences. That dialogue operates at several levels; it includes the rejection of the imperial world by Third World intellectuals and various attempts to establish an alternate view of the imperial experience; active elements which engage in politics and the promotion of nationalist agenda and those that promote Third World issues from their influential positions within the imperial centre. Works which formerly sought to understand the imperial experience from an essentially Western view point are becoming less evident and the new focus is upon analysis of the role of Western culture and its depiction of imperialism. Marxists have been at the forefront of critical studies of imperialism and even though most wrote from within a Western perspective the resulting studies have tended to be sympathetic to anti-colonial aspirations. Several historians have produced carefully nuanced readings of the role of Western culture during the hey-day of imperialist expansion and their work has been supplemented by Edward Said's new book, Culture and Imperialism. ${ }^{2}$

This is a work which uses Said's considerable skills as a literary and cultural critic as a basis for generating a sustained examination of the historical developments of imperialism, and in particular, those expressions of dominance as they appear in the literature of metropolitan centres. He seeks to demonstrate the unconscious manner

2 Edward W. Said, Culture and Imperialism (New York 1993); See for example, V.G. Kiernan, The Lords of Human Kind (London 1972) and his Marxism and Imperialism (New York 1974); E.J. Hobsbawm, The Age of Empire, 1875-1914 (London 1989) and Hobsbawm and T. Ranger (eds.), The Invention of Tradition (New York 1983). The essays by Hobsbawm are included under the rubric of Marxism; Harry Magdoff, Imperialism: From the Colonial Age to the Present (New York 1978); Gordon K. Lewis, Slavery, Imperialism and Freedom: Studies in English Radical Thought ( New York 1978); There are obviously many more works that could be cited here but one other work should be noted; Homi Bhabha, The Location of Culture (London 1994). This has just been published and according to the brief review by Terry Eagleton it resembles Said's book in "describing how the West came to construct a systematic knowledge of its colonial subjects in order to regulate them more efficiently." Guardian Weekly, 6 March 1994, 28. 
in which both author and audience accept the nature of the imperial relationship; the almost absent minded association of racial dominance with the right and obligation to rule 'inferiors.' For Said, following Blake's admonitions on the relationship between culture and empire, ${ }^{3}$ these complicated relationships are never considered by the likes of Austen, Dickens, Verdi, Camus. Even Conrad, who wrote so disparagingly of imperialism, was guilty of the cultural acceptance of white domination because he could not appreciate the various levels of cultural attainment achieved in Africa, South America and Asia before contact with the 'white man.' As Said argues "we must take stock of the nostalgia for empire, as well as the anger and resentment it provokes in those who were ruled, and we must try to look carefully and integrally at the culture that nurtured the sentiment, rationale, and above all the imagination of empire. And we must try to grasp the hegemony of the imperial ideology, which by the end of the nineteenth century had become completely embedded in the affairs of cultures whose less regrettable features we still celebrate." 4

In this age of discourse analysis, of deconstruction, of the dominance of the text and the silence of the author, it is refreshing to read a book which goes beyond intellectual posturing, academic fashion, and glib theoretical formulations and attempts to deal with the meat of historical problems. This is a work which enlarges the usual scope of literary criticism and history, combining the two and elaborating and elucidating an extremely sensitive reading of the relationship between Western culture and the sense of imperial mission. It is book of nuanced insight and also a book of special pleading for tolerance and understanding; Said refuses to view the west as entirely culpable for the failures of the post-colonial world and saves a large measure of his criticism for the manner in which superficial nationalist leaders and their projects have managed to create inequalities and intolerance which mirror in some cases the worst excesses of imperialism. And he specifically rejects the idea that we can "build analyses of historical experience around exclusions, exclusions that stipulate, for instance, that only women can understand feminine experience, only Jews can understand Jewish suffering, only formerly colonial subjects can understand colonial experience." 5

The desire to create a significant dialogue between the current metropolitan centres and the former colonial world has led Said to suggest a method of analysis which uses "the perspectives and methods of what might be called a comparative literature of imperialism ... by looking at the different experiences contrapuntally, as making a set of what I call intertwined and overlapping histories, I shall try to formulate an alternative both to a politics of blame and to the even more destructive politics of confrontation and hostility." 6 This method requires the writer to analyze

3 Said, Culture and Imperialism, 13; quoting William Blake, "The Foundation of Empire is Art and Science. Remove them or Degrade them and the Empire is No more. Empire follows Art and not vice versa as Englishmen suppose."

4 Ibid., 12.

5 Ibid., 31.

6 Ibid., 18. 
what appear to be unrelated occurrences in the light of imperialist relations to demonstrate the connections of "discrepant experiences"; thus coronation rituals in England and the Indian durbars of the late nineteenth century which are, upon initial inspection, apparently unrelated, yield an internal coherence once each element has been subjected to analysis. "Discrepant experiences," analyzed comparatively demonstrate the manner in which imperialism has created a series of relationships which cannot be understood one without the another. Although to historians this may not seem particularly new, Said wants to ensure that in future writers will acknowledge that neither imperialism as experienced from the centre nor the imperialism experienced by the former colonies can be divorced, and must be seen as an analytic whole.

Said has created a masterful analysis of the manner in which the habit of imperialism and the justification for its existence became embedded in cultural production. Despite the process of decolonization which has taken place largely during the past fifty years, Said argues that many of the previously unspoken assumptions of Western culture are still manifest in current relationships between the imperial centre, now the United States, and the formerly colonized world. Having said that however, the second part of Said's work is dedicated to elucidating the development of opposition to colonialism and imperialism and to demonstrating just how literature coming from the marginalized colonial world impinged upon and penetrated the consciousness of the west.

In one area Said might have expanded his analysis of the role of literature; for example, he might have considered the impact of language as a tool for developing nationalism because even though we are made aware of the role of literature in the process of domination of the colonial periphery, he does not take into account the fact that the imperial centre was attempting to overcome centrifugal forces within the metropolis, not merely those at the periphery. Utilizing the work of one of his students, The Masks of Conquest by Gauri Viswanathan, Said argues that English studies were originally formulated by colonial administrators "for the ideological pacification and re-formation of a potentially rebellious Indian population." 7 But the point surely is that not only were they used in that particular fashion but that they were also used to impose a particular version of English (or French, in another context) upon those who resided at the centre as well. These forces were often ethnic minorities who constituted a significant cultural and linguistic barrier to national identities and emerging national cultures. To overcome these was the paramount task of the production of a national literature. As Benedict Anderson argues, "at the core of the empires nations too were emerging - Hungarian, English and Japanese. And these nations were instinctively resistant to 'foreign' rule. Imperialist ideology in the post- 1850 era thus typically had the character of a conjuring trick." ${ }^{8}$ Even formal imperialism had significant weaknesses at the centre. We must not forget that Great Britain was the result of a long process of state centralization reaching out from the

$7 \quad$ lbid., 42.

8 Benedict Anderson, Imagined Communities (London 1983), 111. 
metropolitan centre. Wales, Scotland and Ireland constituted the early parts of the empire of the English dynastic state as did the various overseas possessions in the Caribbean and North America. Anglicization, as a cultural process, was as much about the domination of London over the British Isles as it was of the domination of the rest of the Empire by Britain. ${ }^{9}$

The analyses of Jane Austen, Conrad, Verdi's Aida, Camus's L'Etranger, serve to demonstrate the nature of the West's hegemony; a hegemony so complete that the west dominated not only militarily and technologically, but more especially the West dominated through a system of cultural production which established not only the imaginative boundaries of the dominant West but also that of the dominated colonial world; a vision so powerful that it convinced both rulers and ruled of the imperative of Western dominance and made alternatives unimaginable. The very mapping of the world, carried out by those at the imperial centre, suggests cultural dominance. Maps which show large areas of the world in red, or green or yellow, or whatever colour chosen by the imperial power, register the fact of cultural domination by their very existence. No one living at the periphery would have the least doubt about the cultural meaning of such maps. Cartography has often been one means of expressing control over geographic space and in the imperialist enterprise it reached the high point of this particular expression. As Thai historian Thongchai Winichakul explains it in relation to the process by which Siam became "mapped" between 1850 and 1910:

In terms of most communications theories and common sense, a map is an abstraction of reality. A map represents something which already exists objectively "there." In the history I have described, this relationship is reversed. A map anticipated spatial reality, not vice versa. In other words, a map was a model for, rather than a model of, what it purported to represent. ${ }^{10}$

Despite the concentration upon the imperial theme we must not forget that Said is one of the foremost literary critics writing today and his methodology therefore assumes importance. This book is much like Williams' The Country and the City, and Culture and Society; it is an attempt to understand and organize a critique of a very specific historical development through literature and through an understanding of the importance of culture and cultural production in the materialization of dominance. ${ }^{11}$ Both appear to have a similar regard for the work of Gramsci and both

9 Philip Corrigan and Derek Sayer, The Great Arch: English State Formation as Cultural Revolution (Oxford 1985). No series of articles relates this process more thoroughly than the History Workshop series Patriotism: The Making and Unmaking of British National Identity (London 1989) and the work of Linda Colley, "The Apotheosis of George III: Loyalty, Royalty and the British Nation," Past and Present, n.102 (1984); also "Whose Nation? Class and National Consciousness in Britain, 17501830," Past and Present, n. 113 (1985). Tom Nairn, The Enchanted Glass: Britain and its Monarchy (London 1988). Moreover, there are other silences which require attention. For example, a discussion of modern British writers such as the one carried out by Alan Sinfield, Literature, Politics, and Culture in Postwar Britain (Berkeley 1989) would have proved beneficial in view of Said's arguments regarding the nature of culture and the manner of its dissemination.

10 Quoted in Anderson, Imagined Communities, 173 
therefore seek to understand relationships between the dominant and the dominated through the concept of hegemony and through an appreciation of the manner in which culture exerts pressure and sets limits which determine the norms not just of society in general but also of literature and the forces of cultural production. Said substitutes nationalism for class in his approach but the resultant textual and contextual analysis remains much the same. He distances himself quickly from the continental school and develops an argument which stresses the relationship between the text and the author, and between the author and social and historical experiences. For whilst this may not be an ordinary book of literary criticism it remains nevertheless a book of literary criticism which transcends the text and seeks to understand the relationship between culture and the movement of history.

Although Said's analysis of Mansfield Park is highly illuminating, his rather limited depiction of culture as contained within the form of the novel leads to a restrictive view of the relationship between empire and culture in England. And indeed, his analysis of the novel has some significant silences. As a literary critic he may be forgiven for having missed the chapter on property relations in Mansfield Park by historian R.S. Neale in Writing Marxist History, however, what Neale has to say is important and relates very specifically to some of Austen's silences which Said locates. For Neale, Jane Austen has written a novel not only about a system of property relations but also one about the alienation of humanity. Although "it (agrarian capitalism) has its main roots deep in the English countryside and feelers spreading out towards London ... it has also sent out economic tap-roots to the West Indies." ${ }^{12}$ And Austen's purpose in describing these relations was an attempt to deal with the moral dilemma of the slave trade and plantation slavery which provided the economic bolster to Mansfield Park. Essentially Neale argues that "Antigua was the occasion that triggered the fall from propriety of all the main characters in the novel ... It signals the dissolution of a system based upon landed property ... already corrupted by its connections with the urban/mercantile mode of production." 13 That mercantile mode of production was, of course, plantation slavery, and as Neale points out, the two are inseparable in any analysis of the role of landed property and the links to the monied elite.

11 Raymond Williams, Culture and Society, 1780-1950 (Harmondsworth 1961); The Country and the City (St. Albans 1975). For an interesting interview with Williams and Said see Raymond Williams, The Politics of Modernism (London 1990); Appendix entitled "Media, Margins and Modernity," 177-197.

12 R.S. Neale, Writing Marxist History (Oxford 1985), 104.

13 Neale, Writing Marxist History, 107. In another area of cultural production that is crucial to understanding aspects of the relationship between Victorian England and the Empire, that of advertising, Said is silent. His restriction of culture to the novel, whilst understandable, is nevertheless, quite limiting. The novel resonates at the higher level of culture but advertising ramified throughout society and created a series of important icons linked specifically to the relationship between England and the Empire. See, for example, Thomas Richards, The Commodity Culture of Victorian England: Advertising and Spectacle, 1851-1914 (Stanford 1990) particularly Chapter Three entitled "Selling Darkest Africa." 
There are problems with the work, however. Too much literature and not enough history is the main problem. Literature is not history and despite the fact that many historians use the contemporary novel to illustrate their work, the novel only reflects the society of its day and does not set out to be history. Said has not read sufficient history and that creates a series of tensions for the informed reader and leads the unwary astray. Some critics suggest that he has failed to read the most important works in the field; one, J.B. Kelly, even goes as far to say that Said writes incorrect history and that is "what comes of failing to read the right books on the subject." Kelly's work on India leads him to develop a number of pertinent criticisms of the book and although I would not go as far, I would suggest that Said has not created an adequate context for his subject matter and this leads to inaccuracies and outright error in places. Ernest Gellner exposed some errors of Said's arguments about the French Empire and there is little doubt that the scope of the work and his intention to study the role of culture prevented him from dealing adequately with many aspects of the problem of imperialism. Nevertheless, it is the very scope of the work which makes it so impressive and the idea of studying certain cultural manifestations in this manner is both timely and necessary. Although any critic is able to highlight the silences and the omissions within specific fields this does not vitiate the overall argument or detract from the importance of the work. It also, of course, misses the point of the book; the need to move away from particularity and the tribalism so prevalent today.

\section{Two}

Culture and Imperialism represents the analysis of the dominance of the metropolitan centre over the colonial periphery. Customs in Common is the latest volume in E.P. Thompson's evocation of cultural resistance - the resistance of rural England to the advance of agrarian capitalism. This latest book is an integral part of his examination of the eighteenth century which began with The Making of the English Working Class and continued with various articles on food rioting, plebeian culture, patricians and plebeians, and the law of the eighteenth century as seen from the bottom up. ${ }^{14}$ His last book, published just prior to his death, Witness Against the Beast: William Blake and the Moral Law, is the final chapter in a career which was carried out almost completely outside the traditional university environment and which helped to re-create the writing of English history. Thompson is undoubtedly the most important historian of the postwar period in English history and his work is enormously influential, not just in that field but throughout the academic world.

14 E.P. Thompson, Customs in Common (London 1991); The Making of the English Working Class (Harmondsworth 1968); Whigs and Hunters; The Origin of the Black Act (New York 1975); Douglas Hay, Peter Linebaugh, and E.P. Thompson (eds.), Albion's Fatal Tree: Crime and Society in Eighteenth-Century England (New York 1975). 
For a historian of the working class and one who argued very specifically for the importance of agency and the role of class in peoples lives it might seem surprising that Thompson chose to examine aspects of the eighteenth century rather than continue his analysis of the working class, as he did his next book on the Black Act of 1723 and his edited collection on crime and society. But in reality this work made a great deal of sense. One of the most interesting and forceful arguments in The Making of the English Working Class relates to the importance of certain cultural inheritances which played a unique and profound role in the development of working class consciousness. It was to these cultural manifestations that he returned; first in the article on the "moral economy" and then the one on "patricians and plebs" and the role of deference and several others which sought to recover the culture of the poor, of the rural world, a culture which demonstrates a remarkable robustness and which Thompson sees as the basis for developing class consciousness. These concerns were already apparent in The Making of the English Working Class and were therefore a natural progression. Customs in Common and the last book on Blake are part of the same project and represent the culmination of thirty years of scholarly commitment to rescuing "the poor stockinger, the Luddite cropper, the 'obsolete' handloom weaver, the utopian artisan and even the deluded follower of Joanna Southcott, from the enormous condescension of posterity." 15

Customs in Common is not a new work. Comprising two previously published articles, "Time Work-Discipline and Industrial Capitalism," and "The Moral Economy of the English Crowd in the Eighteenth Century," three reworked papers, "Custom and Culture," "The Patricians and the Plebs," and "Rough Music," and two pieces which contain material not previously published but heard at the conference table, "The Sale of Wives" and "Custom, Law and Common Right." These chapters represent a consolidation of views previously expressed and are vintage Thompson. They are also "connected by different paths with the theme of custom ... my thesis [is] that customary consciousness and customary usages were especially robust in the eighteenth century." "They reassert the main arguments of his view of the eighteenth century, the necessity of understanding plebeian culture and the manner in which it was juxtaposed to the dominant patrician culture of the day, the reality of a vigorous and very aggressive agrarian capitalism, and the necessity of understanding the dynamic nature of the relationship between the patricians and the plebeians.

Thompson addresses some of his critics with regard to his view of the eighteenth century and those with various difficulties arising out of the "moral economy" argument. "The Moral Economy Reviewed" is some twenty pages longer than the original article and represents a consideration of the role of the market in society. As he argues, "the 'market' turns out to be a junction-point between social, economic and intellectual histories, and a sensitive metaphor for many kinds of exchange." $\mathrm{He}$

15 Thompson, The Making of the English Working Class, 13.

16 Thompson, Customs in Common, 1. 
provides some commentary upon those who have taken the "moral economy" and developed it not only in the original sense as part of the reality of the eighteentcentury crowd but also those works which have taken it into other lands and used it paradigmatically to inform other histories. Moreover, as this chapter demonstrates, the original article generated a significant response, not just in direct reply in the context of crowd studies, but also in the wider sphere of intellectual activity dealing with studies of peasant communities in Asia, the role of the British in Indian famine, and various considerations of the applicability of the "moral economy" to current market economics. And as he states at the conclusion of the piece, "if I did father the term 'moral economy" upon current academic discourse, the term has long forgotten its paternity. I will not disown it, but it has come of age and I am no longer answerable for its actions." 17

Perhaps Thompson's greatest gift to the historical profession was the literary quality of his prose and the respect he had for literary sources. Rarely has any historian used Blake or indeed the handbill to more effect and his influence in this regard has assisted in promoting such diverse sources to the consciousness of historical discourse. His insistence on studying the process of class relations has benefitted from a careful reading of Fielding, Swift, Blake, Smollett and numerous other literary sources from the eighteenth century. The poet and the ploughman were sources to be mined just as the food rioter had his or her contribution to make. And it was the development of that concern for the validity of the literary experience which led Thompson toward his evocation of the theatricality of relationships and the analysis of the role of symbolic violence. His decoding of food riots and his insistence on the role of the "moral economy" in opposition to Smithian "political economy" represents a superb rendering of the use of such violence and of the essentially relational aspect of rioting.

The "moral economy" was a collective culture which rested upon traditional practices or time-honoured rites and which claimed precedent over individual needs. As such this culture represented a rather conservative ethos and was essentially defensive in the face of that potent solvent: agrarian capitalism. Traditions were to be defended through collective action; riot was endemic to eighteenth-century society and represented a robust symbol of communal intent. More importantly perhaps, riot also existed as one part of the patrician-plebeian relationship; a relationship based upon a reciprocity hammered out through hard bargaining and the residual sense of paternalism which existed amongst the gentry and aristocracy until the close of the eighteenth century: this despite the apparent overthrow of paternalism in 1772 when Parliament rescinded the statutes against market abuse and ushered in the age of Adam Smith and political economy. For Thompson, patricians and plebeians existed

17 Thompson, Customs in Common, 351. See also the work of James Scott, The Moral Economy of the Peasant: Rebellion and Subsistence in Southeast Asia (New Haven 1976); Amartya Sen, Poverty and Famines (Oxford 1981); David Arnold, "Looting, Grain Riots and Government Policy in South India, 1918," Past and Present, n.84 (1979). 
in a mutuality shaped by patrician hegemony but informed and tempered by a plebeian tenacity that clung to a traditional culture and sought to juxtapose cultural norms to capitalist imperatives.

Thompson has been accused of exaggerating the parasitical nature of the early Whig state ${ }^{18}$ he nevertheless successfully demonstrates the rapacious nature of agrarian capitalism and the manner in which it invaded the countryside leaving a trail of broken customs and traditional practices..$^{19}$ Capitalism in England developed out of the agrarian sector; it transformed the countryside with enclosures, with business practices that stressed the importance of the "market" and with the help of a legal code that stressed the rights of private property against those of the community. It must be remembered that Adam Smith wrote a great deal about the necessity of freeing the grain trade from paternalist constraints in order to ensure an adequate supply of food to the entire community. Traditional hisorians rarely discussed the impact of those invasions on rural England and they represented a minor part of those studies which sought to understand the role of the agrarian economy in the industrial revolution. In this sense we cannot assess this book separately from his earlier books and articles because they constitute one related piece of work. We also cannot separate the man from his social context because Thompson is highly sensitive to the prevailing political climate of England during the past decade and his discussion of the "market" reflects that concern.

What is achieved throughout his work is the provision of an alternative view of society that always maintains a perspective based upon class analysis and human agency. There is no quaint romanticization of the working class or of plebeian society; he acknowledges the conservative, protective nature of "plebeian" culture and that the crowd was often chauvinistic and as likely to be acting as a "Church and King"

18 Perhaps the best consideration of Thompson's parasitical argument is contained in Perry Anderson, Arguments within English Marxism (London 1980). He suggests three main criticisms. The first is that evidence demonstrates that the massive increase in capital crimes was not matched by executions, which infact, decreased from the senenteenth century. Secondly, "the religious cynicism combined with the subordination of the Church to factional interests," which Anderson points out led to the "laicization of the Established Church which contribute[d] precisely to cultural and intellectual emancipation from it." Thirdly, the role of the state which was characterised as a "banana republic." Which as Anderson points was a term used to denote a relatively weak state, but which cannot characterise the English state; the Hanoverian state was an ascendant colonial power and had just defeated the French. The manner in which Walpole wielded power differed little from previous governments and his accumulation of wealth resulted from a lengthier term in office than most other ministers. Anderson cites Namier to the effect that "corruption in eighteenth century England can be seen as the index and instrument of a mollification of conflicts within the ruling class after the lethal proscriptions and executions of the previous century." (Anderson, 93-94.)

19 Thompson, Customs in Common, Chapter 3; see also the work of John Walter, "The Social Economy of Dearth in Early Modern England," in John Walter \& Roger Schofield (eds.), Famine, Disease and the Social Order in Early Modern Society (Cambridge 1989); for a superbly documented study of the problems of dearth and state mechanisms at the close of the eighteenth century see, Roger Wells, Wretched Faces: Famine in Wartime England, 1793-180I (Gloucester 1988); also see, John Bohstedt, Riots and Community Politics in England and Wales, 1790-1810 (Cambridge, Mass. 1983). 
mob at the urging of the local Tory establishment in the latter years of the eighteenth century as it was to be a crowd bent upon disciplining those who abused the market place in times of dearth. The independent stance of the labouring poor might have progressed in the period after 1790, but chauvinism and jingoism are important aspects of working-class culture that have been exploited to serve specific political agenda which characteristically ignore the needs of those so manipulated.

There are some silences in the work; for example, we rarely glimpse the burgeoning middle class of Georgian England, or if we do they are merely lackeys toadying up to the patricians. ${ }^{20}$ Thompson has never been at ease with this bourgeoisie, especially those farmers and grain dealers whose attachment to property and profit mirror that of the rapacious gentry. They appear as the scapegoats of dearth; greedy farmers who would rather keep the grain in their barns than bring it to market and get too low a price; grain dealers who bought the grain in bulk from the farmer and circumvented the traditional market by selling it to a maltster or brewer before market time. There is no sense that bourgeois individualism might have found a place in the hearts of the labouring poor and that the growing commercialism of the mid-eighteenth century was producing a consumer society which included not only the bourgeoisie but also those at the lower end of society. Capitalist relations in the marketing of grain were well established, and the exploitation of farming coupled with the export bounty meant that England became a net exporter of grain in the period between 1660 and 1780 . The decline of the traditional pitching market was not confined to the eighteenth century; evidence suggests that its demise came earlier, and the role of London as a market of central importance which drew effectively on its hinterland and further away as the city grew, coupled with the rise of smaller centres of consumption such as Bristol, Liverpool, Norwich and by mid-century several more towns, helped to speed its passing. ${ }^{21}$ In addition, the middle class were not as compliant and acquiescent as we are led to believe. During at least two riotous outbreaks at mid-century, farmers and businessmen began to speak out against their socially assigned role of scapegoats for food shortages. Not only did many of them write pamphlets and letters to the growing number of provincial and London newspapers, but they also began to argue against paternalism, seeking to blame the labouring poor for their own plight because they refused to act rationally

20 See the exchange between Dale Williams, "Morals, Markets and the English Crowd in 1766," Past and Present, 104 (1984) and A. Charlesworth and Adrian Randall, "Morals, Markets and the English Crowd in 1766," Past and Present, 114 (1987).

21 For example E.A. Wrigley, "A Simple Model of London's Importance in Changing English Society and Economy, 1650-1750," Past and Present, 37 (1967); E.A.Wrigley, "Urban Growth and Agricultural Change: England and the Continent in the Early Modern Period," in P. Borsay (ed.), The Eighteenth Century Town (New York 1990). W.E. Minchinton, "Bristol: Metropolis of the West in the Eighteenth Century," Transactions of the Royal Historical Society, 5th Series, iv,1954. 
110 left history

and switch to alternative food sources. In many of these criticisms we hear the voice of political economy and those voices heard throughout the land in the years leading up to 1834 and the passage of the Poor Law Reform Act. ${ }^{22}$

Customs in Common represents the best of Thompson. Written in a polemical and highly personal style, it is never less than superb in its command of the sources and speaks from the commitment of an often idiosyncratic yet highly moral scholar. He met the world on his own terms and often found it wanting; sadly there will be no more interventions like The Poverty of Theory or those collections of the committed defender of liberty such as Writing by Candlelight or The Heavy Dancers. Said will no doubt make many more interventions; Culture and Imperialism is a provocative book which attempts to address the cultural basis of an imperialistic attitude which remains firmly entrenched.

22 Jeremy Caple, "Provisioning, Paternalism and the Moral Economy," a paper given at the "Moral Economy Twenty-One Years on Conference," Birmingham, April 1992: and currently under revision for submission for publication. There are a number of pamphlets published during the period 1757-58, in direct response to the dearth experienced between August 1756 and December 1757, which caused widespread rioting with at least 130 serious riots reported in the press and government documents. It was during this period of dearth that what amounted to a national campaign of "scapegoating" implicating farmers and grain merchants in shortages, drew a significant response from members of the middle class decrying the accusations and pointing out the advantages of the grain trade and farming for profit. 